\title{
KAJIAN PENGETAHUAN DAN PERILAKU MENYUSUI PADA IBU PRIMIGRAVIDA DI KELURAHAN SOLOK SIPINKECAMATAN TELANAIPURA
}

\section{STUDY KNOWLEDGE AND BEHAVIOR OF BREAST-FEEDING FOR MOTHER PRIMIGRAVIDA IN SOLOK SIPIN VILLAGE TELANAIPURA DISTRIC}

\author{
Efni Roza Julia L ${ }^{1)}$, Aprizal Lukman ${ }^{2)}$, Evita Anggereini ${ }^{3)}$ \\ e-mail:rozalubis47@gmail.com \\ Staf Pengajar Prodi Pendidikan Biologi FKIP Unja
}

\begin{abstract}
This study aims to determine the knowledge and behavior of primigravida mothers in breastfeeding her baby held in District Telanaipura. Tomeasure the level of knowledge primigravida ie using an objective test with multiple-choice type of questions as many as 20 items, and to measure the behavior of lactating primigravida using interview guide as 6 questions with respondents ie 15 primigravida. The results showed that, the benefits of breastfeeding and how to breastfeed right has three categories namely high percentage of $33.33 \%$, while the percentage of $13: 33 \%$ and lower the percentage of $53.33 \%$, while for the behavior of lactating mothers included in the category of active feeding. However, the breastfeeding mother is still a lot of mistakes 33\% of mothers during breastfeeding schedule and $93 \%$ of mothers are still breastfeeding at one position so that the attachment of the areola with the baby's mouth is not good cause ASI issued also not optimal. To maintain the health of $25 \%$ of mothers wash hands before feeding, and $80 \%$ of mothers did not clean the nipples after breastfeeding. Another factor affecting the mother is a lack of interest in reading books or references regarding how breastfeeding is good and right, as well as the lack of socialization of health care workers on how to breastfeed correctly.
\end{abstract}

ABSTRAK Penelitian ini bertujuan untuk mengetahui pengetahuan dan perilaku ibu primigravida dalam menyusui bayinya di Kabupaten Telanaipura. Untuk mengukur tingkat pengetahuan primigravida yaitu dengan menggunakan uji objektif dengan pilihan jenis pilihan ganda sebanyak 20 item, dan untuk mengukur perilaku primigravida laktasi dengan menggunakan pedoman wawancara sebagai 6 pertanyaan dengan responden yaitu 15 primigravida. Hasil penelitian menunjukkan bahwa, manfaat menyusui dan cara menyusui kanan memiliki tiga kategori yaitu persentase tinggi yaitu 33,33\%, sedangkan persentase 13 : $33 \%$ dan menurunkan persentase 53,33\%, sedangkan untuk perilaku ibu menyusui termasuk pada kategori makan aktif Namun, ibu menyusui masih banyak melakukan kesalahan $33 \%$ ibu selama menyusui dan $93 \%$ ibu masih menyusui pada satu posisi sehingga keterikatan areola dengan mulut bayi tidak baik karena ASI dikeluarkan juga tidak optimal. Untuk menjaga kesehatan $25 \%$ ibu mencuci tangan sebelum menyusui, dan $80 \%$ ibu tidak membersihkan puting susu setelah menyusui. Faktor lain yang mempengaruhi ibu adalah kurangnya minat baca buku atau referensi tentang bagaimana menyusui baik dan benar, serta kurangnya sosialisasi petugas kesehatan tentang cara menyusui dengan benar.

Kata kunci: Pengetahuan Belajar, Ibu Primigravida dan Desa Solok Sipin 


\section{PENDAHULUAN}

Air susu ibu (ASI) tidak tergantikan oleh susu manapun. Bayi yang mendapatkan ASI akan lebih sehat, lebih cerdas, mempunyai kekebalan terhadap berbagai penyakit dan secara emosional akan lebih nyaman karena kedekatan dengan ibu. Air susu ibu (ASI) adalah cairan tanpa tanding yang diciptaan Allah SWT. Fungsinya yaitu untuk memenuhi kebutuhan bayi dan melindunginya dalam melawan kemungkinan serangan penyakit. Keseimbangan zat-zat gizi dalam ASI berada pada tingkat terbaik. ASI juga sangat kaya akan sari-sari makanan yang mempercepat pertumbuhan sel-sel otak dan perkembangan system saraf. Susu formula atau makanan-makanan tiruan untuk bayi yang diramu menggunakan teknologi canggih sekalipun tidak akan sanggup menandingi keunggulan ASI ciptaan Allah SWT (Widiyanto,dkk, 2012:26).

\section{Menyusui adalah proses yang} alamiah yang tidak mudah dilakukan sehingga untuk mencapai keberhasilan menyusui diperlukan pengetahuan mengenai teknik-teknik menyusui yang benar (Kuntarti, dkk, 2011:2). Menyusui merupakan suatu proses alamiah, namun untuk mencapai keberhasilan menyusui diperlukan pengetahuan ibu mengenai cara menyusui yang benar, dari sini dapat diambil kesimpulan bahwa pengetahuan mengenai cara menyusui yang benar sangat penting dalam proses menyusui (Apriyani,dkk,2014:38).

Primigravida adalah seorang wanita hamil yang untuk pertama kali (Sudaryanto, 2010:1) selain itu primigravida adalah ibu yang baru pertama kali melahirkan anak pertamanya dan baru pertama kali melakukan aktivitas menyusui. Pada primigravida ibu baru pertama kali akan menyusui bayinya, selain itu belum ada pengetahuan mengenai ASI dan cara pemberiannya (Wardani, 2012:16).

Pengetahuan merupakan hasil dari tahu dan ini terjadi setelah seseorang melakukan penginderaan terhadap suatu objek tertentu. Dari hasil tahu tersebut seseorang dapat melakukan kegiatan yang diinginkannya. Pengetahuan ibu tentang ASI (Air Susu Ibu) yaitu seberapa besar ibu mengetahui mengenai ASI, manfaat dan dan cara memberikan ASI (Suryaningtyas dan Winarsih, 2010:114).

Perilaku adalah totalitas penghayatan dan reaksi yang dapat langsung terlihat atau yang tidak tampak. Timbulnya perilaku akibat dari interaksi stimulus internal dan eksternal yang diproses melalui kognitif, afektif dan psikomotorik (Pieter dan Lumongga, 2011:28). 
Di Indonesia rata-rata bayi hanya diberi ASI eksklusif kurang dari dua bulan. Ada beberapa hal yang menghambat pemberian ASI, diantaranya adalah karena rendahnya pengetahuan para ibu mengenai manfaat ASI dan cara menyusui yang benar, kurangnya pelayanan konseling laktasi dan dukungan dari petugas kesehatan, persepsi-persepsi sosial-budaya yang menentang pemberian ASI, kondisi yang kurang memadai bagi para ibu yang bekerja (cuti melahirkan yang terlalu singkat, tidak adanya ruang di tempat kerja untuk menyusui atau memompa ASI), dan pemasaran agresif oleh perusahaan perusahaan pembuat susu bayi yang tidak hanya mempengaruhi para ibu, namun juga para petugas kesehatan (Setiyowati dan Khilmiana, 2010:2).

Kegagalan dalam proses menyusui disebabkan karena timbulnya beberapa masalah, baik masalah pada ibu maupun bayi.Pada sebagian ibu yang tidak paham tentang cara menyusui yang benar, kegagalan menyusui sering dianggap sebagai problem pada anaknya saja. Selain itu ibu sering mengeluh bayinya sering menangis atau "menolak" menyusu, dan sebagainya yang sering diartikan bahwa ASI nya tidak cukup, atau ASI nya tidak enak, tidak baik sehingga sering menyebabkan diambilnya keputusan untuk menghentikan menyusui (Dardiana, dkk, 2011:46).
Pendidikan kesehatan ialah suatu upaya atau kegiatan untuk menciptakan perilaku masyarakat yang kondusif untuk kesehatan. artinya, pendidikan kesehatan berupaya agar masyarakat menyadari atau mengetahui bagaimana cara memelihara kesehatan mereka, bagaimana menghindari atau mencegah hal-hal yang merugikan kesehatan mereka dan kesehatan orang lain. kesehatan bukan hanya diketahui atau disadari (knowledge) dan sikapi (attitude), melainkan harus dikerjakan/laksanakan dalam kehidupan sehari hari (practice). Hal ini berarti bahwa tujuan akhir dari pendidikan kesehatan ialah agar masyarakat dapat mempraktikkan hidup sehat bagi dirinya sendiri dan bagi masyarakat, atau masyarakat dapat berperilaku sehat (healty life style) (Notoatmodjo, 2012:14).

Hasil wawancara peneliti pada tanggal 22 Oktober 2015, saat mengikuti kegiatan posyandu di wilayah kerja Puskesmas Putri Ayu Kelurahan Solok Sipin pada ibu primigravida dengan latar belakang tingkat pendidikan Sarjana, SMA dan SD, dari ketiga ibu tersebut hanya satu yang memahami tentang pemberian ASI tetapi belum mempraktikkan cara menyusui yang benar karena pada saat menyusui bayinya masih menangis, dan dua ibu lainnya masih memberikan makanan pendamping ASI. Selain itu, peneliti juga melihat para ibu 
ketika sedang menunggu giliran untuk imunisasi ibu memberikan ASI ditempat yang terbuka, sehingga tidak membuat bayi nyaman ketika disusui bayi menangis.

Hasil observasi yang di lakukan peneliti pada tanggal 24 Oktober 2015 di laksanakan di Kelurahan Solok Sipin, Kecamatan Telanaipura. Peneliti menggambarkan pengetahuan yang rendah dan perilaku yang salah dalam praktik menyusui sehingga menyebabkan rendahnya pencapaian pemberian ASI, membuat peneliti tertarik untuk meneliti seberapa jauh pengetahuan dan perilaku ibu dalam menyusui anaknya. dari uraian tersebut peneliti tertarik untuk melakukan penelitian.

\section{METODE PENELITIAN}

Penelitian ini merupakan penelitian deskriptif kualitatif. Penelitian deskriptif kualitatif adalah penelitian yang memberikan gambaran tentang keadaan dan gejala-gejala sosial tertentu secara naturalistik karena penelitiannya dilakukan pada kondisi yang alamiah (Sugiyono, 2014:15).

\section{Subjek Penelitian}

Subjek penelitian ini adalah ibu primigravida yang memiliki bayi usia 0-6 bulan di wilayah kerja Puskesmas Putri Ayu, Kelurahan Solok Sipin, Kecamatan Telanaipura. Teknik pengambilan data yang digunakan adalah purposive sampling yaitu menentukan subjek penelitian dengan pertimbangan tertentu yang dipandang dapat memberikan data secara maksimal dengan mengambil 15 orang ibu primigravida

\section{Jenis Data}

Jenis data yang dikumpulkan sesuai dengan kebutuhan peneliti yaitu data kualitatif. Data kualitatif berupa gambaran dari masing-masing indikator yang meliputi pengetahuan ibu dengan menjawab benar pernyataan berkaitan dengan pengetahuan menyusui yang berjumlah 20 butir secara tes objektif dan perilaku menyusui peneliti menggunakan wawancara tidak terstruktur berjumlah 6 pertanyaan.

\section{Teknik Pengumpulan Data}

Pengumpulan data pada penelitian ini dilakukan dengan beberapa cara yakni: Observasi, menyebarkan kuiseoner berupa tes objektif, wawancara dan dokumentasi.

\section{Teknik Analisis Data}

Data yang di peroleh dari hasil penelitian nantinya akan dimasukkan kedalam tabel dengan memasukkan kode yang di buat oleh peneliti dan disusun sesuai dengan kebutuhan dan tujuan penelitian, lalu secara deskriptif kualitatif data akan diolah menggambarkan masing-masing variabel dan menganalis faktor-faktor lain 
yang diperkirakan mempengaruhi ibu dalam menyusui.

\section{Perhitungan Skor Pengetahuan (Tes)}

Untuk mengetahui pengetahuan ibu primigravida dalam menyusui anaknya, peneliti menggunakan tes tertulis dengan jenis soal pilihan ganda dengan jawaban yang telah disediakan, sehingga responden tinggal memilih jawaban sesuai pengetahuannya. (Sugiyono,2012: 95) Untuk perhitungan skor pengetahuan (tes) sesuai dengan rumus berikut ini:

$$
P=\frac{\mathrm{X}}{\mathrm{N}} \times 100 \%
$$

Keterangan:

$\mathrm{P}:$ Persentase pengetahuan

$\mathrm{X}$ : Jumlah jawaban benar

$\mathrm{N}$ : Jumlah seluruh pertanyaan

Menurut Wawan dan Dewi, (2011:18) Tingkat pengetahuan primigravida diinterpretasikan dengan skala yang bersifat kualitatif sebagai berikut:

a. Tinggi, apabila hasil persentase ibu menjawab benar 76\%-100\%

b. Sedang, apabila hasil persentase ibu menjawab benar 56\%-75\%

c. Rendah, apabila hasil persentase ibu menjawab benar $<56 \%$

\section{Penilaian Terhadap Perilaku Menyusui}

$\begin{array}{ccc}\text { Pengukuran } & \text { perilaku } & \text { ibu } \\ \text { primigravida yang menyusui } & \text { peneliti }\end{array}$

menggunakan pedoman

wawancara.

Dimana peneliti menggunakan wawacara terstrukur. Dimana jawaban dari responden akan dideskripsikan pada lembar pedoman wawancara.

\section{Analisis data}

Data yang diperoleh dari dokumentasi akan dianalisis secara deskriptif. Penulis hanya akan menggambarkan bagaimana pengetahuan dan perilaku ibu saaat menyusui.

\section{HASIL DAN PEMBAHASAN}

\section{Hasil Penelitian}

Penelitian mengenai pengetahuan dan perilaku berkenaan dengan menyusui yang telah dilakukan di wilayah kerja puskesmas Putri Ayu Kelurahan Solok Sipin, Kecamatan Telanaipura. Subjek penelitian adalah ibu primigravida yang memiliki bayi usia 0-6 bulan yang berjumlah 15 orang.

\section{Karakteristik Responden}

\section{Umur Responden}

Data yang diperoleh menunjukkan rata-rata umur responden berusia 25 tahun dan 30 tahun yang berjumlah masingmasing 4 orang persentase $26,7 \%$, dan berumur 28 tahun berjumlah 2 orang dengan persentase $13,33 \%$, dan 5 orang berrumur masing-masih 19 tahun, 21 tahun, 26 tahun dan 29 tahun dengan masing-masing persentase $6,67 \%$. 


\section{Tingkat pendidikan responden}

Data yang telah diperoleh tingkat pendidikan responden terbanyak yakni ibu yang memiliki tingkat pendidikan SMA sebesar sebanyak 11 orang dengan persentase $73,33 \%$, dan responden dengan tingkat pendidikan akhir perguruan tinggi berjumlah 2 orang dengan persentase 13,33\%, dan ibu dengan tingkat pendidikan terakhir SMP berjumlah 1 orang dengan persentase $6,67 \%$ dan ibu dengan tingkat pendidikan terakhir SD berjumlah 1 orang dengan persentase $6,67 \%$.

\section{Pekerjaan ibu}

Data yang telah di peroleh sebagian besar responden hanya sebagai ibu rumah tangga berjumlah 13 orang dengan persentase $86,67 \%$. sedangkan yang paling rendah adalah ibu yang bekerja sebagai non PNS (guru honorer) dengan jumlah 2 orang dengan persentase $13,33 \%$.

\section{Penghasilan Ibu}

Berdasarkan data yang diperoleh responden yang paling banyak yakni respoden yang tidak memiliki penghasilan yakni berjumlah 13 orang dengan persentase $86,67 \%$, dan 1 orang ibu memiliki penghasilan <1000.000 dengan persentase $6,67 \%$, sedangkan 1 orang memiliki penghasilan tertinggi yakni kisaran Rp.1000.000-Rp.2000.000 dengan persentase $6,67 \%$.
Data Tingkat Pengetahuan Menyusui Ibu Primigravida Di Kelurahan Solok Sipin Kecamatan Telanaipura

Tingkat pengetahuan ibu primigravida mengenai ASI ibu memiliki tingkat pengetahuan yang rendah dengan persentase $53,33 \%$ dan ibu yang memiliki tingkat pengetahuan tinggi yakni 33,33\%.

\section{Deskripsi perilaku menyusui ibu primigravida}

Ibu memberikan ASI 2 jam sekali sebanyak 5 ibu sedangkan 10 ibu primigravida tidak menjadwalkan saat menyusui dan untuk perilaku atau tindakan menyusui dari 15 ibu hanya 1 orang ibu perilaku dan posisi menyusui yang benar. Dari $15 \mathrm{ibu}, 10 \mathrm{ibu}$ primigravida tidak mencuci tangan sebelum menyusui dan $5 \mathrm{ibu}$ primigravida mencuci tangan sebelum menyusui. Hampir semua ibu primigravida tidak pernah membersihkan puting susunya setelah selesai menyusui.

Mengenai pengetahuan tentang kandungan ASI yakni dari 15 responden 9 orang ibu menjawab kandungan terbesar dalam ASI adalah karbohidrat dengan persentase $60 \%$ dengan tingkat pengetahuan sedang. Untuk vitamin dalam ASI, dari 15 responden 12 orang ibu menjawab vitamin A di dalam ASI berfungsi menjaga kesehatan mata selain itu juga berfungsi mendukung 
pembelahan sel, kekebalan tubuh dan pertumbuhan dengan persentase $80 \%$ masuk dalam kategori tingkat pengetahuan tinggi. Dari 15 responden 10 orang ibu mengetahui kandungan ASI yakni sebagai penghasil kalori.

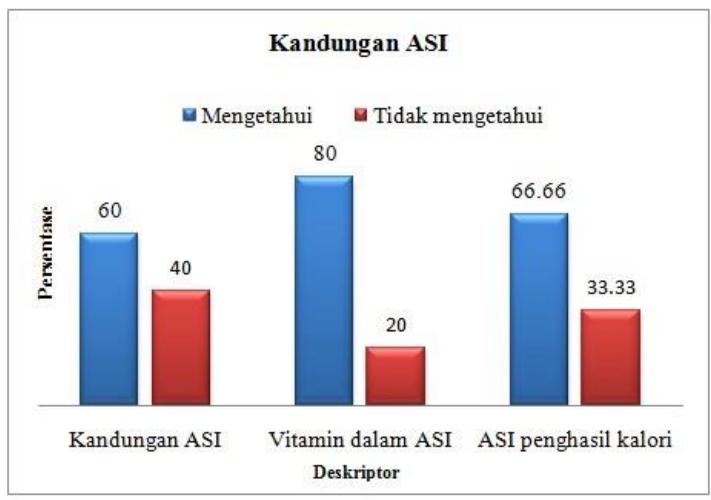

Gambar 1. Pengetahuan kandungan ASI

Pengetahuan ibu tentang manfaat ASI bagi bayi cukup tinggi. Ibu mengetahui salah satu manfaat ASI untuk bayi dengan persentase $100 \%$. salah satu manfaat menyusui bagi bayi adalah memberi rasa nyaman dan aman antara ibu dan anak. Pemahaman ibu tentang antibodi dalam ASI mencegah bayi dari demam dan flu juga tinggi dengan persentase $100 \%$ ibu mengetahui manfaat ASI untuk otak bayi dengan persentase $93,33 \%$. ibu mengetahui risiko yang dapat di hindari bayi jika di beri ASI dengan persentase $66,66 \%$, Ibu mengetahui bahwa kekebalan (imunitas) di peroleh bayi dari ASI dengan persentase $100 \%$.

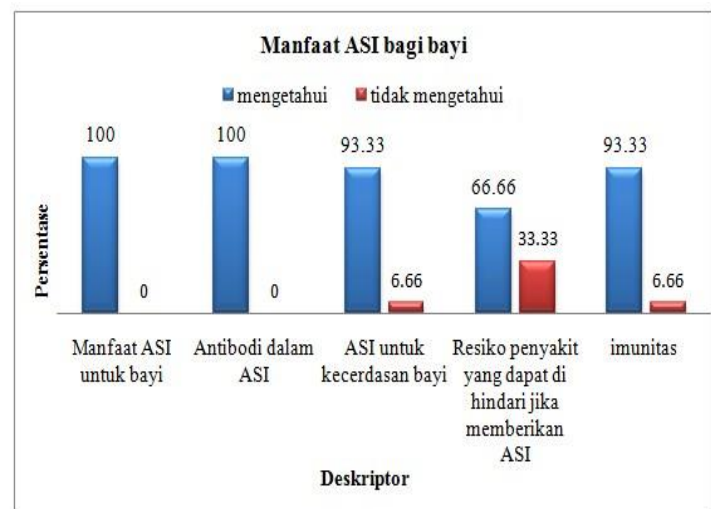

Gambar 2. Pengetahuan ibu tentang manfaat ASI untuk bayi

Pengetahuan ibu tentang manfaat menyusui bagi ibu. Ibu memahami asi untuk dirinya sendiri dengan persentase $53,33 \%$, ibu juga mengetahui manfaat asi untuk kesehatan ibu dengan persentase $66,66 \%$.

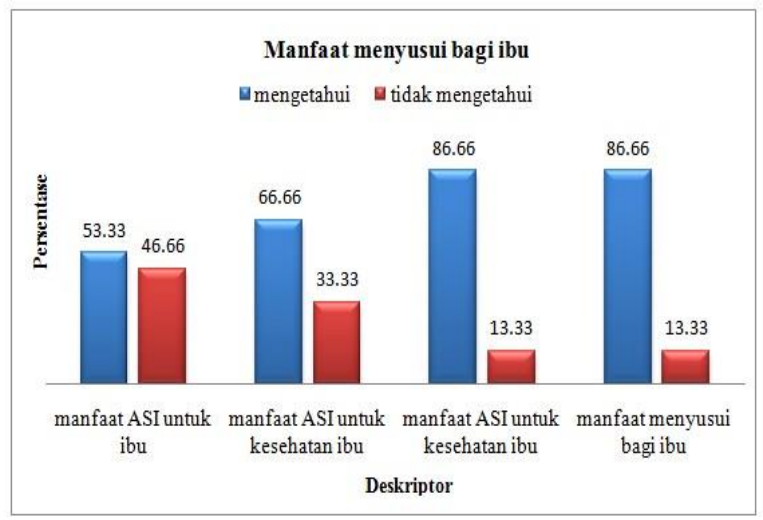

Gambar 3. pengetahuan manfaat menyusui bagi ibu

Pengetahuan ibu tentang cara menyusui banyak ibu yang tidak mengetahui tentang cara menyusui. Dari pernyataan yang salah mengenai cara menyusui yang benar ibu menjawab tiap payudara harus disusukan hingga habis, dengan persentase $86,66 \%$. Selanjutnya, ibu tidak mengetahui akibat cara menyusui yang salah dapat mengakibatkan putting 
susu menjadi lecet dengan persentase 73,33\%. Ibu tidak memahami ciri menyusui dengan benar dengan persentase $53,33 \%$ dan ibu tidak memahami hal yang perlu diperhatikan ibu saat menyusui dengan persentasi 53,33\%.

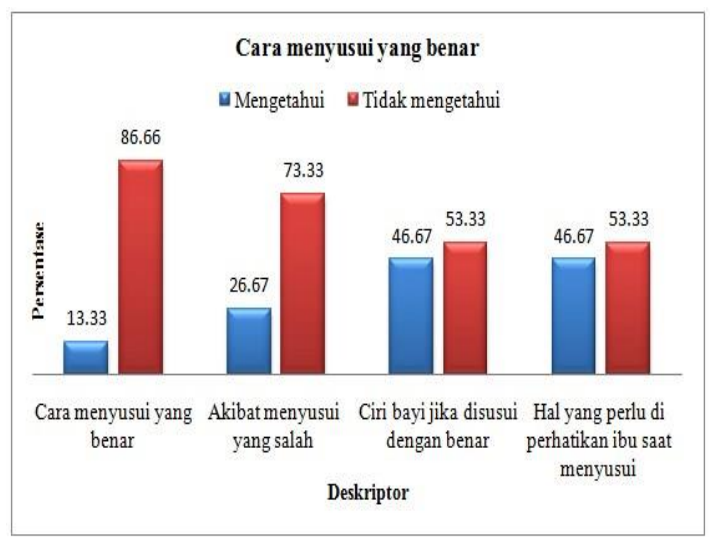

Gambar 4. Pengetahuan tentang cara menyusui Yang benar

Mengenai indikator menyusui yang benar yakni dapat di lihat ibu mengetahui ciri bayi tampak tenang ketika disusui dengan persentase sebanyak 53,37\%.

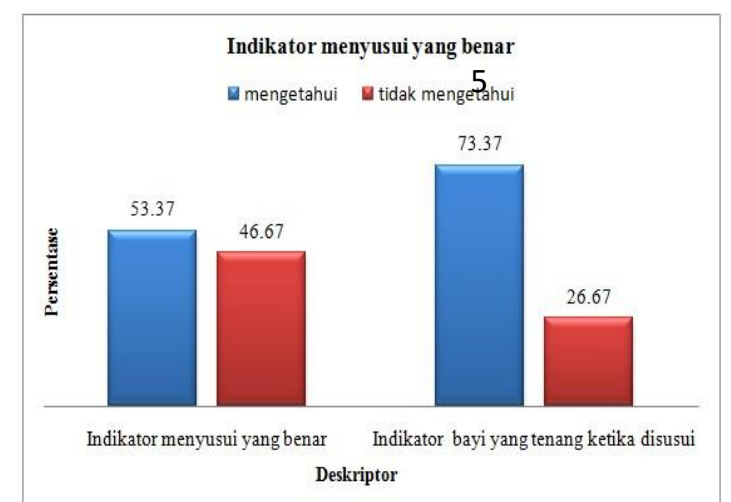

Gambar 5 Pengetahuan tentang indikator menyusui Yang benar

Pengetahuan ibu tentang waktu menyusui dan frekuensi saat memberi ASI. ibu tidak memahami jika bayi tidak terjadwal saat menyusui dengan presentase $53,33 \%$. Ibu kurang mengetahui waktu yang tepat ketika menyusui, dan ibu tidak mengetahui frekuensi (waktu) menyusui yang tepat bagi dengan persentase $60 \%$.

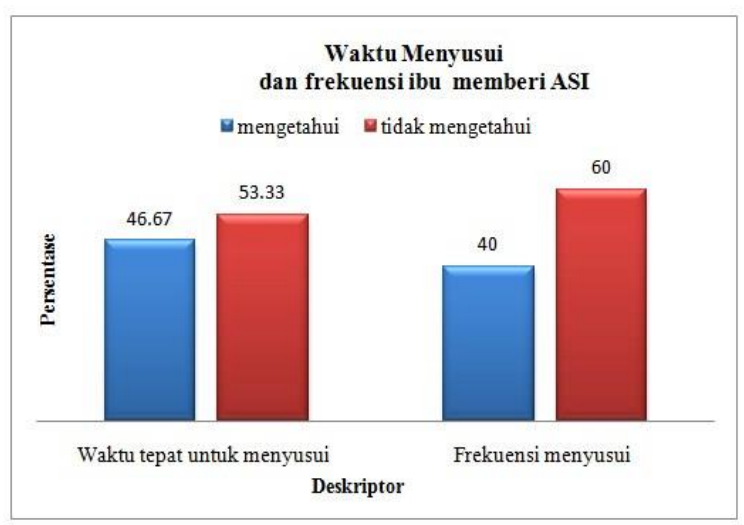

Gambar 6. Pengetahuan ibu tentang jadwal menyusui

Hasil penelitian menunjukkan pengetahuan ibu mengenai pengertian ASI dan kandungannya serta manfaat ASI cukup tinggi. Namun, untuk cara menyusui pengetahuan ibu masih tergolong rendah. Ada beberapa faktor yang menyebabkan ibu primigravida hanya memahami tentang ASI dan kurang memahami cara menyusui yang benar. Ada beberapa faktor yang menyebabkan hal tersebut terjadi yakni faktor kurangnya pengalaman ibu dalam menyusui, karena ibu primigravida biasanya belum ada pengalaman dalam menyusui anaknya. Selain itu faktor pendidikan, pada penelitian ini $73,37 \%$ ibu batas terakhir pendidikannya yakni lulus SMA, selain itu pekerjaan ibu yang rata-rata ibu rumah tangga, dan menghabiskan waktunya dirumah. Mereka tidak ingin mencari informasi yang lebih terkait cara menyusui yang dan faktor lingkungan 
juga mempengaruhi karena rata-rata ibu hanya berkelompok dengan orang-orang tingkat pendidikannya setara dengan sesama mereka, jadi mereka tidak mendapatkan informasi yang lebih. Setelah itu, kurangnya minat mereka dalam mencari informasi cetak maupun elektronik juga mempengaruhi pengetahuan mengenai ASI. selain itu kurangnya sosialisasi dari pihak kesehatan mengenai ASI dan cara menyusui yang benar.

Perilaku menyusui ibu primigravida di Keluharan Solok Sipin Kecamatan Telanaipura termasuk aktif namun perilaku kurang baik saat menyusui, ibu masih menjadwalkan saat menyusui dengan persentase $33 \%$ dimana rata-rata 2 jam sekali ibu menyusui anakanya alasanya bayinya menangis biasanya 2 jam sekali, untuk menjaga kebersihan yakni $75 \%$ tidak mencuci tangannya sebelum menyusui. menunjukkan $\quad 80 \%$ ibu tidak membersihkan puting susunya setelah menyusui hal ini menunjukkan rendah ibu daam menjaga kesehatan untuk dirinya sendiri walaupun hampir ibu memberikan ASI selama 6 bulan, namun dari cara proses menyusui masih banyak yang salah. Hal ini dikarenakan ibu tidak terlalu memperhatikan cara menyusui yang benar cara yang salah berakibat pada kuantitas ASI yang di keluarkan. puting ibu menjadi lecet karena perlekatan antara puting susu dengan mulut bayi yang salah.

\section{KESIMPULAN DAN SARAN}

\section{Kesimpulan}

1. Pengetahuan menyusui ibu primigravida di Kelurahan Solok Sipin Kecamatan Telanaipura tentang pengetahuan ASI yang terdiri atas 3 kategori untuk pengetahuan tentang ASI, manfaat ASI dan cara menyusui yang benar yakni ibu yang memiliki pengetahuan tinggi berjumlah 5 orang dengan presentase $33.33 \%$, yang memiliki tingkat pengetahuan sedang berjumlah 2 orang dengan presentase $13.33 \%$, dan memiliki tingkat pendidikan rendah berjumlah 8 orang dengan presentase $53.33 \%$.

2. Perilaku menyusui ibu primigravida di Kelurahan Solok Sipin Kecamatan Telanaipura, termasuk aktif namun, proses menyusui ibu masih banyak melakukan kesalahan yakni, seperti masih menjadwalkan ketika akan menyusui ibu menyusui dengan posisi yang masih salah sehingga perlekatan areola dengan mulut bayi tidak baik menyebabkan ASI yang dikeluarkan juga tidak optimal.

\section{Saran}

1. Pengembangan kurikulum mengenai perilaku menyusui belum pernah di dapatkan sekolah. Ini merupakan 
pembelajaran yang perlu dipelajari disekolah karena suatu saat siswi akan menjadi seorang wanita yang akan mempunyai anak, ini menjadi dasar yang nantinya membuat mereka lebih dekat dengan anaknya.

2. Adanya penyuluhan mengenai cara menyusui yang benar dari pihak kesehatan.

\section{DAFTAR RUJUKAN}

Apriyani.,Kritiyanti.,Susiatmi

2014.

Pengetahuan Ibu Nifas Tentang Teknik Menyusui Dengan Kejadian Puting Susu Lecet. Jurnal Ilmu Kesehatan.6(1):38.

Dardiana.,Mifbakhudin.,Mustika.2011. Hubungan Antara Pendidikan, Pekerjaan Dan Pengetahuan Ibu Dengan Teknik Menyusui Yang Benar Di Desa Leteh Kecamatan Rembang Kabupaten Rembang. Jurnal Kebidanan.1(1).

Kuntarti,T.,Wuryanto,A.,Ratnaningsih,E. 2011.Gambaran Karakteristik Ibu Nifas Dan Praktik Menyusui Yang Benar di Rumah Sakit Panti Wilasa Citarum Semarang,Jurnal kebidanan panti wilasa.2(1):2.

Notoatmodjo,S.2003. Promosi Kesehatan Dan Perilaku Kesehatan.

Jakarta:Rineka Cipta.

Pieter Heri Jan dan Lubis Namora Lumongga. 2011. Pengantar Psikologi Untuk Kebidanan. Jakarta:Kencana Predana Media Group.

Setiyowati dan Khilmiana, 2010. Hubungan Pengetahuan Tentang Asi Eksklusif Pada Ibu Bekerja Dengan Pemberian Asi Eksklusif. Jurnal Kebidanan.11(1):2.

Sudaryanto. 2010. Diakses pada tanggal 19 januari 2017. Konsep Dasar Primigravida.
Suryaningtias dan Winarsih. 2010. Hubungan Tingkat Pengetahuan Ibu Tentang ASI Eksklusif Dengan Perilaku Pemberian ASI Eksklusif Di Puskesmas Nguter. Semarang.Jurnal Kesehatan. 2(4):114.

Sugiyono. 2012. Metode penelitian Kuantitatif Kalitatif dan $R \& D$. Bandung: Alfabeta.

Wardani Mujianti Alifah. 2012. Gambaran Tingkat Self-Efficacy

Untuk Menyusui Pada Ibu Primagravida. Skripsi, Universitas Indonesia: Fakultas Ilmu Keperawatan.

Widiyanto,S.,Aviyanti,D.Tyas, M. 2012. Hubungan Pendidikan Dan Pengetahuan Ibu Terhadap Pemberian ASI Eksklusif. Jurnal Kedokteran Muhammadiyah.1(1): 26.

Wawan, A dan M, Dewi. 2011. Teori dan Pengukuran Pengetahuan dan Sikap Dan Perilaku Manusia. Yogyakarta: Nuha Medika. 